\title{
Непубликуваните фикционални текстове (Васил Попович и Асен Христофоров)
}

\begin{abstract}
Aretov Nikolay, Nepublikuvanite fikcionalni tekstove (Vasil Popovič i Asen Hristoforov) (Unpublished Fictional Texts [Vasil Popovich and Asen Hristoforov]). "Poznańskie Studia Slawistyczne" 19. Poznań 2020. Publishing House of the Poznań Society for the Advancement of the Arts and Sciences, Adam Mickiewicz University, pp. 149-168. ISSN 2084-3011.

This paper deals with some texts from the archives of two authors from different periods. These texts were not published by the authors in their lifetime. The reason was not some kind of censorship, especially in the case of Vasil Popovich, who probably had some scruples dealing with events from the private life of his opponent Konstantin Jireček. Asen Hristoforov, a writer who was expelled from the University and sent to a labor camp, did not offer texts about his time in the labor camp for publishing. However, in this published texts there are hints about the repressions he suffered and about his disapproval of the communist regime. At the same time, there was a tension between his criticism and his attempt to partially accept the official perspective towards some events and political figures of Bulgarian communist past.
\end{abstract}

KEYwORDS: unpublished; fiction; censorship; personal relations

Непубликуваните текстове на значимите автори представляват интересно предизвикателство пред изследователите. Пьрвият въпрос, който те неизбежно пораждат, е за причините, поради които тези текстове не са достигнали до публиката. И основният отговор, разбира се, е цензурата в широкия смисьл на думата - самата тя, опасенията, че текстът ще бъде санкциониран или отхвърлен от цензорите или от редакторите, опасенията от реакциите на контролиращите институции след евентуална публикация. В значителна част от случаите това, разбира се, е вярно. Струва ми се, обаче, че то не изчерпва проблема. Допускам, че в някои случаи то е лесното обяснение, което може да попречи да се навлезе в сложността на проблема. 
През десетилетията след падането на Берлинската стена бяха публикувани текстове от писателското чекмедже и други, излизали в цензуриран вид. По-малко, отколкото се очакваше. Някои от фикционалните творби сред тях привлякоха вниманието, в повечето случаи не за дълго. Появата им бе съпътствана с множество реакции, в някои случаи приближаващи се до откровена реклама, какъвто бе по-новият случай с второто издание на романа Калуня-каля (2014) на Георги Божинов. Няколко бяха и публикациите на дневници и други нефикционални текстове за близкото минало - Чудомир (1994), Й. Вълчев (2004), К. Константинов (2011), П. Динеков (2016)... На най-голям интерес и на най-интензивно цитиране като че ли се радва дневникът на Б. Делчев (1995), което е обяснимо с неговия обхват и богатството на факти. Същевременно при него като че ли и прочитьт е и най-политизиран, при това, струва ми се, доста безкритично. При него, а в някои други случаи (например Чудомир), желанието да се попълни галерията на инакомислещите и, едва ли не дисидентите, може да доведе до не съвсем основателно героизиране / виктимизиране.

Вниманието тук ще се насочи към няколко примера от различно време, които допускат и дори предполагат по-комплексно осмисляне. На първо място това са фикционални текстове, останали непубликувани. Към тях могат да се прибавят и някои документални текстове, писани сякаш само за архива, но и с неизречената цел да достигнат до публиката в някакъв бъдещ момент, може би след смъртта на автора. Впрочем, надеждата за бъдещо публикуване вероятно е общо място за практически всички писателски текстове, останали в архива. Едва ли са чак толкова много текстовете, писани само за да се изрази нещо (чувство, концепция, реакция), които авторът им да създава само за себе си. Поне в българската литература подобни примери трудно могат да бъдат намерени.

Разгледаните текстове са останали в архивите. Много по-късно, в единия случай - повече от век след смъртта на автора, в другия - след десетилетия, имах възможността да ги публикувам в издания на съчиненията им. Събирането им на едно място, освен субективната нагласа на автора на тези страници, е свързано и с желанието за разкриването на някакви трайни явления. Ще рече, да се излезе от представата за непубликуване единствено поради османската и патриаршеската, 
а и руската цензура преди 1879 , цензурата над комунисти и леви автори през $30^{\text {-те }}$ и $40^{- \text {те }}$ години на XX в. и цензурата по времето на НРБ.

Васил Попович (1833-1897) е интересен и сравнително продуктивен книжовник, който публикува немалко творби, но в архива му се намират и непубликувани текстове, не е изключено да има и изгубени и неразпознати. Характерът му е тежък, след годините на учение в Московския университет той не става част от някаква група, нерядко влиза в конфликти, а и като че ли не е склонен да споделя с други хора своите занимания.

Една непубликувана творба на Попович представлява по-специален интерес. Житейският материал, на който тя се опира, провокира любопитството на днешния читател, а и косвено разкрива важни страни от манталитета, разбиранията и душевните борби на автора. В разказа Възпоминание за чуждите нрави в София. Дон Жуан (Попович, 2000, 258-267) е представен мъж, който изоставя бременната си любовница и бяга в чужбина. Героят обяснява своето заминаване с по-различни мотиви: „Хората са тука мизерни [...] малодушни, интриганти. Тука човек не може нищо да направи, освен да се мъчи денем и нощем напразно. Станал съм сред вас като вампирин“. Намесени са и не особено похвалните нрави на двореца, като моралната присъда е произнесена от една консервативна и патриархална гледна точка.

Сюжетът провокира читателя да потьрси прототипите на героите, които са представени с напълно условни инициали - А., Х., Г. Преди време лансирах хипотезата, че донжуанът може да се свърже с Константин Иречек (Аретов, 2000). Изразът „чуждите нрави“ от заглавието подсказва, че става дума за чужденец, при това „знаменитост“, „един от нашите просветители“, посрещнат с отворено сърце от българите, като една от основните причини за това положително отношение са и славистичните занимания на Иречек. Героят има червена (на друго място „чифутска“) брада и прилича на „евреин, пришелец от Русия или от Румъния“. Накрая той заминава набързо, подгонен от обстоятелствата. Споменаването на Русия или Румъния вероятно трябва 
да маскира твърде директното назоваване на познатата личност и едва ли е сериозен аргумент срещу предлаганата хипотеза.

Иречек пристига в България през 1879 г. и става главен секретар на Министерството на народното просвещение, след това министьр, а накрая - председател на учебния съвет и директор на Музея и Библиотеката. На 1/13 септември 1884 г. той заминава за Прага, където поема катедра в университета. Малко парадоксално личността, която се противопоставя на Иречек и на „чуждите нрави“, е Васил Попович. Той никак не е подходящ за говорител на традиционния битов консерватизъм. Всичко в живота му го отнася по-скоро към лагера на „проевропейски“ настроените българи от това време, при това с показателното в случая уточнение за близост до славянофилските среди. Но отношенията между Иречек и Попович са обтегнати. Иречек по принцип е доста строг към българите, понякога е мнителен и прави впечатление на надменен (Аретов, 2011в). В дневника си Иречек на няколко пъти иронизира Попович. Изглежда с Дон Жуан българинът си отмъщава на ироничния и самоуверен чужденец.

Прельстената хубавица от разказа, която очевидно не е случайна личност, също провокира любопитството. Тя се оказва приближена до двореца, на нея е била „врьчена“ „една част от судбата на софиянците, за да не кажа по-голяма дума“. Днес имаме неочакваното и рядко срещано предимство да можем да видим сюжета през очите на сатирично представения герой, при това също публикуван много по-късно. В дневника си Иречек сравнително често споменава Клотилда Цветишич, с която очевидно е близък и към която храни приятелски чувства, но никъде не я назовава своя годеница. Вместо това през октомври 1884 той отбелязва: „На 16, в четвъртък стояло във вестниците (»Politik«), че тези дни щял съм да се женя в Загреб“ (Иречек, $1995,548)$.

Престоят на Клотилда Цветишич в София не минава без скандали. Но Иречек винаги взима нейна страна и не допуска възможността да спомене „чудните работи“, които по-късно били излезли наяве. През ноември 1882 г. той отбелязва:

Клика от няколко любители на народната просвета (Шишеджиев, Д. Македонски и т.н.) пръсна слух, че в девическия пансион имало сифилис. Не излезе нищо 
друго, освен скрофули, и то само един случай; изследваха работата д-р Петрович, д-р Калевич, д-р Христов. Тази компания не може да се даде под съд, вече поради скандала; всичко това бърка Шишеджиев, от три години все същата история. И с какви украшения разказваха цялата тази история: болестта била не само in genitalis, ами more turco и от зад! От част беше насочена срещу Mlle Ц.; тримата загребски възпитаници и аз сме имали уж с нея alliance etroite и пр. и пр. (Иречек, 1995, 237).

Поведението на Цветишич, Иречек и тримата българи ,загребски възпитаници“ очевидно дразни патриархално настроените местни консерватори. И тук едва ли става дума само за по-либерално поведение, критикувано от патриархална гледна точка. Иречек сам разкрива отношението, което той и Клотилда - двама високообразовани централноевроейски славяни имат към българите. През септември 1882 г. Клотилда и Иречек се срещат случайно на дунавския параход, който ги отнася към българските земи, самочувствието на Иречек е поласкано, че тя си спомняла неговите мъдри думи: „Човек може да привикне, да се аклиматизува на Изток, ала не бива да излиза вън - впечатленията от Запад правят връщането в Ориента много горчиво“ (Иречек, 1995, 188). Ясно е, че под Ориент тук се разбира България, а Прага и Загреб попаднат в очертанията на Запада. Ефектната фраза кара Иречек да забрави дори симпатиите към природата и народа, декларирани другаде. Днес изглежда практически невъзможно подобни реплики, а и по-общите представи, които стоят зад тях, да не бъдат разглеждани през призмата на противопоставянето Запад - Ориент, видяно в контекста на тоталната му критика, разгърната от Едвард Саид (1999; Todorova, 1997).

При това очевидно не става дума само за общи съждения за българите, Иречек не пропуска възможността да бъде и по-конкретен. Изглежда с Дон Жуан българинът си отмъщава на ироничния и самоуверен чужденец. Нека припомня, че става дума за непубликувани текстове, друг е въпросът, че и Попович, и Иречек вероятно са говорели подобни неща публично и те не биха могли да останат тайна за засегнатия. Трети въпрос е, че днес дневникът на Иречек оставя впечатление, че е замислен и писан за публикуване след смъртта на автора. Ако се остави настрана фактическата достоверност на клюките и твърденията, която едва ли е толкова важна, можем да забележим, че Попович и Иречек се обвиняват взаимно в сходни грехове (Аретов, 2011а). 
На пръв поглед изглежда, че в случая се сблъскват два възгледа. При това едва ли само за Ориента или жената и отношенията ѝ с мъжа. Иречек привидно заема една по-либерална и по-просветена позиция, докато Попович се оказва в лагера на патриархално настроените консерватори. Предпоставеността и конкретните житейски обстоятелства побеждават реалната близост между двамата. Сходството в обвиненията като че ли подсказва, че конфликтът не е между патриархален и модерен „европейски“ морал, а по-скоро между две сходни личности, овладени от широко разпространени предразсъдъци и лични пристрастия. Както и между представители на двете крила на славянската идея - руското и централноевропейското. Либералните и консервативните обвинения се оказват само аргументи, оръжия в един по-друг сблъсък. Привидно той е личностен, но под повърхността се крие конфликтът между две социални роли, между две роли в обществото и свързаните с тях дискурси (Аретов, 2011a).

Едната роля е на осъзнатия цивилизатор, дошъл в Ориента отвън, за да донесе плодовете на просвещението и да ги наложи, ако трябва и със сила. Втората роля е на туземния интелигент, креолския по определението на Бенедикт Андерсън (1998, 61 и сл.), който се бунтува срещу „цивилизатора“, защото не приема отредената му позиция на обект на цивилизоване и въобще на по-ниско поставен. В конкретния случай той дори може да се чувства ограбен, защото му е отнета ролята на цивилизатор, която ако не е играл, то поне е репетирал многократно - и като литератор и публицист, и като учител и общественик. Може да се допусне, че става дума не толкова за сбльсък между две гледни точки, колкото за конкурентна борба за заемане на една важна и за двамата роля - тази на цивилизатора. Всъщност и Попович, и Иречек идват „отвън“, оформили са се другаде, българинът също се е чувствал неразбран и недооценен, амбициите и идеалите им са сходни (Аретов, 2011а).

За да се формулират позициите на двете страни трябва да се използва някакъв наличен, вече изграден език. Езикът на Попович пази спомена за (дали да не кажа - използва инструментално) дискурса на страха от заплахите на „европеизма“ и „криворазбраната цивилизация“, ако си послужим с езика на Възраждането, стреми се да изгради един по-модерен „оксиденталистки“ дискурс. Това го поставя редом 
с недобронамерените клюкари, които коментират живота на Цветишич, несъзнателно обективирайки някакви свои скрити желания. Същевременно патриархалният тон на разказа, осъждащ „чуждите нрави“, не ще да е без европейски аналогии, които надхвърлят европейска лексика - не само Дон Жуан или употребеното като нарицателно име „дулсинея““ (Аретов, 2011а).

Другата роля умело, макар и доста механично черпи клишета като „ориенталски харемски идеи“ и „полувизантийския характер“ от изградения високомерен, предпоставен, а и не безкористен европейски дискурс за Ориента. Но всъщност чак толкова либерален ли е Иречековия вариант на европейския дискурс? (След Саид може да се попита и дали архетипьт му е либерален). Чужденецът също се оказва склонен да използва патриархални аргументи в обвиненията си срещу Попович, дори и в личния си дневник, т.е. когато сякаш е насаме със себе си. Патриархалното мислене се проявява и в това, че той всъщност не разкрива мотивите за разваления годеж между Иречек и Цветишич. Ясно е, че неговият жест има своята сложна мотивировка, вероятно само частично осъзната, както и свое оправдание за пред другите и особено пред себе си. Би могло да се допусне, че гледан от Прага Загреб също може да изглежда „ориенталски“. Но отказът да се запише каквото и да е оправдание вероятно говори за гузна патриархална съвест, която надделява над оправданието. Несъмнено патриархален е и намекът, че годеникът всъщност се подчинява на волята на семейството (Аретов, 2011a).

Остава въпросът защо текстът на Попович не е достигнал до съвременниците. За цензура в тесния смисъл на думата едва ли може да се говори. Не е ясно дали разказът въобще е предлаган за публикуване; не е изключено да е бил отхвърлен от издатели, които са разпознали ненаименованите персонажи. Данни за нещо подобно не се откриват, а и то е малко вероятно. Иречек наистина е авторитет, но той има и политически противници, които биха приели охотно представянето му в негативна светлина. А пресата и тогава е жадна за подобен тип истории. По-вероятно изглежда у самия автор да са възникнали скрупули, които са го накарали да задържи за себе си (и за бъдещи читатели) портрета на нехаресвания чужденец и сюжета, свързан с него. Подобни мотиви вероятно определят и непубликуването на Иречековите 
текстове. Не е изключено и скрупулите на Попович в някаква степен да са свързани с нежеланието да демонстрира амбицията си да влезе в ролята на цивилизатор.

Асен Христофоров (1910-1970) е писател по неволя и интелектуалец с особена съдба. Учи в Цариградския Робърт колеж, след това завършва и икономика в Лондонския университет. След юношеските увлечения по литературата, неговите основни амбиции се насочват към науката, а и към обществената активност. Професионален писател Христофоров става след уволнението от Университета (1947), и след освобождаването му от лагера в Белене (1952), където попада по обвинение за шпионаж в полза на Англия. След пьрвата му и много успешна книга Скици из Лондон (1945), той активно публикува икономически студии, възможност, която му е отнета от властта след уволнението. Няколко години след лагера той започва да публикува под псевдоним, да превежда от английски, да пише краеведски изследвания. На литературната сцена излиза след 1957 г., но и до края литературните му творби, които се радват на добър читателски интеpec, компенсират невъзможността за изява като икономист.

В архивите са запазени няколко непубликувани приживе текста на Христофоров за деветте месеца, прекарани в Белене. Те са по-различни от познатата му автобиографична проза. В тях ужасът е предаден директно, няма място за отстранение и ирония. Писателят едва ли се е надявал да ги види отпечатани. Посмъртно до нас достига разказьт му Пожелай ми безсъние (Христофоров, 1990б, 55-59; Христофоров, 2013, 426-429), явно не единствен опит да се обрисува царството на мрака. Текстьт документира един епизод - жестоко и безсмислено убийство на лагерник, позволил си да открадне една зелка. Повествованието е накъсано, бих казал експресионистично, свързано със сънища, с кошмари - все елементи, нетипични за прозата на Христофоров.

Слез 1990 г. до читателите достигат един разказ на Христофоров, който е по-близо до автобиографичната му проза - Г-н Кандид от Говедаричи (Христофоров, 1990а; вж. и Христофоров, 2013, 417-425). Събитията са малко, вниманието е съсредоточено върху психологията на 
персонажите. А и върху психическите травми от репресиите и последвалото мизерно съществувание. Не е ясно кога е писан разказът, но той отвежда към най-мрачния период от живота на Христофоров. Възможно е да представя събития непосредствено преди арестуването.

Това са един тип непубликувани текстове на Христофоров. Тяхното публикуване очевидно е било невъзможно приживе и не е известно те да са предлагани за печат. От друга страна, Христофоров умело вмества в публикуваните си творби намеци за лагерните си преживявания. Нещо повече, струва ми се, че за времето си Христофоров в най-голяма степен прекрачва границата на позволеното. Но не всички негови непубликувани разкази са свързани с лагера или с критики към режима. Съществуват и други, които не са попаднали в книгите му по тематични или някакви други причини. Такъв е случаят и с Хлапак (НЛМ, № а2889/88) - безопасен разказ за среща след екскурзия на Витоша.

В спомените за Христофоров на няколко пъти се прокрадва мотивът за негов амбициозен замисъл за голяма творба със съвременен сюжет. Съпругата му споменава за такъв замисъл, поне частично осъществен - незавършен роман със заглавие Разлом - ,за величието и падението на нашата бивша буржоазия“ (Христофорова, 1991). За него знаят и други съвременници. Но ръкописът не се открива в богатия архив на писателя в Националния литературен музей и Централния държавен архив. Самият Христофоров споделя за подобни планове или поне информатор на ДС документира подобни разговори:

той му споменал, че има намерение да напише голяма книга (която да удари в земята и „Тютюн“ и „За Свободата“), с която възнамерява да закрепи и заздрави политическото си положение, което мисли все още за разклатено. Той се изказал, че темата за романа си ще черпи от живота на бившите индустриалци сочейки за пример голямото семейство на Паланковите, които и преди 9. XI. 1944 и след тази дата успяха, чрез компромиси отново да се наредят. С това смята да ги разобличи напълно.

Той споменал за Светлозар Паланков, като загатнал, че е човек на ДС, но изрично добавил, че това не можел да твърди с положителност (Христофоров, 2010, 442).

Христофоров като че ли се колебае, бои се. Така поне го е запомнил Йордан Василев: 
Срещах го на площад „Славейков“ и по централните улици на София, сближихме се и неизбежно стигнахме до темата за неговите патила. Подтиквах го да ги опише. Той замълчаваше и след дълга пауза отвръщаше: - Рано е, ще ме смажат (Василев, 1990, 3).

Христофоров е автор на поне два непубликувани и жанрово неопределени текста, които представляват пародийни хроники - едната на Говедарци, а другата - на събитията в България по време на Втората световна война. И двете стьпват на документални източници, подобно на двата му романа, като хрониките също са фикционални, но по различен начин.

Ръкописът Последните мацуакуриуи. Летописни бележки за едно бивше цуарско село не е датиран. Сюжетът свършва преди 1956 г., нищо не подсказва за следващите събития, поне не в запазения текст. В последния абзац Христофоров пише:

А даскал Митко Мъзганът? [...] Денем той учеше децата, говореше им понякога за великия Сталин, за безсмъртния Георги Димитров, за родния Червенков и младите мацакурчета го слушаха с отворени уста. А вечер, когато се стъмни и по етера се разнасяха зловонията на вражеските радиостанции, ще приседне до приемника, ще завърти копчето, ще нагласи стрелката и дълго ще слуша в захлас „Гласът на Америка”. После, тръпнейки в сладостно предусещане, той ще каже на глас, сякаш сам да си даде кураж: „Ще дойдат те, ще дойдат, и тогава всички ще разберат кой е даскал Митко Мъзганът!“ Унесен в мечти, последният мацакурец заспиваше върху лъскавата кутия на радиоприемника... (Христофоров, 2012, 510-511).

„Последните мацакуричи“ представлява пародийна история на Говедарци. Христофоров е написал сериозната история в краеведската книга Искровете (1962), а един по-сбит вариант присъства в пътеводителя Говедаричи и околностите му (1967). Различни по жанр текстове на Христофоров са посветени и на Самоков, в някои от тях също се споменава Говедарци. При хрониката авторът излиза извън рамките на конкретното село и неговото минало и я допълва с един очарователен вариант на популярната през 70-те и 80-те години у нас „народопсихология“. Преди това Райко Алексиев публикува една интересна Хумористична история на българите (1937), по-късно и други автори 
ще навлязат в този жанр, най-познатият пример е - Краткосмешна история на България (1990) на историка Николай Генчев, публикувана под псевдонима Никола Веранов.

И нещо наистина уникално - близо две десетилетия след смъртта на Христофоров излиза книга от неговия прототип, посветена на същия обект - краеведският труд на Димитър Мазганов Говедарии, включен в поредицата Роден край на Издателство на Отечествения фронт през 1988 г. Няма съмнение, че авторът е „даскал Митко Мъзганът“ от ръкописа на Христофоров. Името на писателя, пришелец в селото, липсва в труда на местния краевед. Христофоров обаче споменава своя „колега“ сред познатите си от селото още през 1951 г., по време на разпитите в Държавна сигурност (Христофоров, 2010, док. № 52).

Пред нас са два разказа, два мита - единият е сериозен, „официален“, политически коректен, другият - пародиен. В единия се представя „своето“, родният край, в другия повествователят недвусмислено заема позицията на пришълеца. Единият се заиграва с „културната интимност“ (М. Хърцфелд), другият се опитва да си служи с „официалния“"по това време дискурс на локалната история.

Последните мацакурии несъмнено е посветена на първо място на съвременността. Така и започва - с общо представяне на селото и неговите жители, с техните нрави и характер. Но историята на селото има своята древност, своя мит за възникване, който присъства и в Мацุакуризи и който всъщност не отпраща много назад във времето. Следват епизоди за царското време, при тях особено ясно проличава многопосочността на иронията - авторът представя с усмивка и в негативен план както монарха, така и селяните. Фердинанд се държи като надменен и гнуслив цивилизатор сред аборигени, селяните охотно приемат натрапената им роля и се стремят да се възползват от нея. Усилията на цар Борис да помогне на своите поданици са по-искрени, но не и по-успешни поради вродената склонност на мацакурци към злоупотреби (Аретов, 2011б).

Въпреки че се занимава подробно с царете и местните управници, Христофоров пропуска един факт от историята на селото, който не може да не му е известен - Мара Малеева е разпределена като участьков лекар в Говедарци (1938-1942), а Тодор Живков „пребивава като 
нелегален в селата Дъскот, Лесичево, Говедарци“; тук, през 1942 г. е родена и дъщеря им Людмила.

Мазганов отново прави точно обратното. В главата Говедари̧и от времето на капитализма прескача всичко свързано с царете (а то спокойно би могло да бъде предадено в духа на историографията от времето на социализма), но не пропуска присъствието на Мара Малеева и Тодор Живков; при него Людмила Живкова също е в немилост и е премълчана (Мазганов, 1988, 76-77).

Най-разгърнати са епизодите, посветени на следдеветосептемврийската история на Мацакурово, в които съществена роля играе авторът на краеведската книга. Тук сатирата на Христофоров е най-жлъчна, а детайлите повече. Личи си, че писателят е натрупал доста горчивини. Може би и заради това той всъщност повтаря пропагандната митологема от това време, а и от следващите десетилетия, за добрите комунисти, за младите, които ще се разправят с бившите хора, които са заграбили властта и користно се представят за комунисти (Аретов, 2011б).

Ето как Христофоров представя пьрвото разпределяне на властта в селото след 9 септември 1944:

Тъй разправяше Мъзганът, а към обед, когато кръчмата се понапълни, той вече действаше като временен секретар на дружбата. Митко Калинката, бъдещият председател, му беше обещал той да представлява дружбата в местния отечественофронтовски комитет, а Калинката държеше на думата си. Няма значение, мислеше си Мъзганът, че в комитета той може би ще свири на втора цигулка; но тия хитреци - даскал Георги, комисарят Крум и даскал Любен - при толкова други млади и изтъкнати комунисти, вероятно не щяха да влязат изобщо в оркестъра... (Христофоров, 2012, 499).

Краеведската книга на Мазганов помага при разпознаването на реалните хора, въведени в повествованието, и при датирането на събитията.

$* * *$

Друга непубликувана приживе и недатирана творба на Христофоров е Хунияда (съвременна хроника) от А. Г. Х. (Христофоров, 2013, 430-509). Хунияда е напълно фикционално произведение, в което са вплетени много автобиографични и документални елементи. То е написано от името на Абарамбо - зулус, който посещава България, 
и „редактирано“ от българина професор Агехев, който носи много от чертите на Христофоров. Представени обикновено с прозвища, в повествованието са въведени редица важни фигури, предимно от политическия живот в България. Един от периферните персонажи, който почти не присъства в сюжета, но за когото главният герой и повествователят говорят, е Стефан Американеца - българин, който живее в Кения, от него Абарамбо е научил български.

Историята на ръкописа е предадена в специален Предислов от редактора, в който е посочен и литературният образец - „прочутият ръкопис на професор Тойфелдрьок, открит навремето от англичанина Томас Карлайл и издаден с коментари на самия Карлайл в спретнато томче под надслов »Сартор резартус«“. Друга сравнително ясна литературна отпратка в текста води до Волтеровия Кандид, който пък отпраща към философията на Лайбниц: „Като предохранителна мярка обаче управниците все пак препратиха в нарочни почивни домове из провинцията няколкостотин столични жители, които, в разрез с известни философии и със самите разбирания на управниците, не намираха, че живеем в най-хубавия от възможно най-хубавите светове...“. Хунияда съзнателно се приближава до повествователен модел на романа от епохата на Просвещението и специално до Волтер, и използвания от него жанр, наричан в български превод „философски роман“" (conte philosophique) (Аретов, 2017).

В рамките на Христофоровия автотекст Хунияда може да бъде съпоставяна с Последните мацакурии - и двете творби могат да бъдат разглеждани като пародийна история, едната е локална, но с по-широк хронологически обхват, авторът я определя като „летописни бележки“; другата, наречена „съвременна хроника“, е национална, посветена е на един сравнително кратък, но много съществен период от няколко години. За разлика от Последните маццакуризи в Хунияда има литературен сюжет - зулусът се влюбва в лекомислена българска девойка, която се възползва от неговата щедрост, след това го изоставя заради немски офицер, по-късно двамата отново се събират. Тази интрига остава на по-заден план, отношенията между персонажите често са само загатнати.

Хунияда, или поне запазеният ръкопис, остава недовършен. Според съдържанието, поставено в началото, творбата е трябвало да се 
състои от тринадесет глави плюс Предислов... и Послеслов от редактора, като пьрвите единадесет имат заглавия, дванадесетата няма, а заглавието на тринадесетата е задраскано и не може да се прочете. И тук събитията са ясно датирани и започват „във февруарското утро на лято 1941“. Повествованието достига до бомбардировките и до „януарий, в година хилядо деветстотин четиридесет и четвърта“. Текстьт изглежда относително завършен, но заглавията на следващите глави - VIII. Деветий септември, XI. В началото бе хаос, X. Съд народен, съд господен, XI. Вечната диалектика - показват докъде във времето е трябвало да стигне повествованието.

Декларираната в предислова цел на повествователя е ,да следи и отбелязва всичко във връзка с нравите и обичаите на съвременните българи, да държи подробни бележки за всички по-важни събития и да представи дневника си, след изтичането на определения срок от време, на престолонаследника на земята на Убанги-шари“.

Българите и особено техният политически живот са представени през очите на един подчертано външен наблюдател, който като че ли не знае нищо за тях. Авторът не се стреми към някакво правдоподобие при главния персонаж Абарамбо. Той е зулус, което ще рече чернокож, но всъщност кожата му има „матов тен“, тъй като майка му е французойка, и фактически не само не се набива на очи, но и дори в някои случаи минава за българин. От една страна, той не трябва да знае нищо за България и да се учудва на всичко, от друга обаче той знае доста добре български, който е научил от Стефан Американеца (Аретов, 2017).

Повествованието е фрагментарно, сюжетът среща чужденеца с няколко постоянни персонажи, които не просто контактуват с зулуca, но и охотно му разказват за своята страна. Те са представителни за определени социални групи и линии в политическия живот; те предоставят и възможности на африканеца да попадне на места или ситуации, които авторът смята за важни (Аретов, 2017).

В записките на Абарамбо, наред с личните му преживявания, акцентът пада върху хода на политическите събития и различните партийни формирования. Основната част от персонажите имат ясни политически възгледи. Професор Агехев, който е „редактор“ на текста и най-често обяснява видяното от зулуса, клони към Звено, подобно на 
Христофоров. По-неясни са възгледите на индустриалеца Зарев, който като че и в политическо отношение е близък до звенаря Агехев. Те по някакъв начин са свързани с едно от „звенарските величия“ - полковник, бивш затворник - визира се Дамян Велчев (1883-1954), който е осъден на доживотен затвор и амнистиран през 1940 г. (Аретов, 2017).

Инженер Сандев „принадлежи на крайната десница“, което ще рече, че е привърженик на Генерала (ген. Христо Луков ${ }^{1}$ ) и неговия Легион (Съюза на българските национални легиони). Близък до него е един капитан, командир на ловна дружина, която преследва „шумарите“ (т.е. партизаните). Дантев пък е „служебно предаден към личния кабинет на Негово Величество царя на българите“2 (Аретов, 2017).

Абарамбо не успява да се срещне с Генерала, но пък вижда един друг известен политик, представен като по-стар колега на Агехев от университета, юрист. Той клони към крайната десница, критикува Кобурга, но обикаля около двореца в Царска Бистрица с надежда да получи отново министерски пост. Епизодът присъства в непубликуваната творба Скици из Рила, където той е пряко назован - Александър Цанков, който обаче е икономист (Аретов, 2017).

Сред въпросите, по които персонажите спорят, е и етногенезисът на българите и т.н. хунска теория, която по това време се стреми да измести славянската. Както е известно, тезата за тъждествеността на хуните с прабългарите, възникна през XIX в., е развита от Васил Н. Златарски в първия том на История на българската държава (1918). Неведнъж тя е подлагана на критика от Ал. Бурмов, В. Бешевлиев, Д. Ангелов и много други историци. В Хунияда теорията е представена иронично, повествователят я възприема, „редакторът“ избягва да я коментира, а Христофоров е още по-дистанциран (Аретов, 2017).

В предислова „редакторьт“ пише:

Колкото се отнася до термина „Хунияда“, Абарамбо бе извънредно упорит той остана докрай с дълбокото убеждение, че българите са хуни, т.е. от хунски

${ }^{1}$ Ген. Христо Луков (1888-1943). Убит от бойна група на БКП пред дома си в София. Такава е съдбата и на персонажа на Христофоров.

${ }^{2}$ Една по-смела хипотеза би допуснала, че прототип на индустриалеца Зарев може да е Светозар Паланков (приятел на автора от Робърт колеж и Лондон), а на царедвореца Дантев - Станислав Балан, син на проф. Ал. Теодоров-Балан и секретар на цар Борис III. 
произход! Даже събитията след историческия акт от 9 септемврий 1944 година не можаха да убедят Абарамбо в обратното. [...] Бъдещето ще покаже доколко избраното заглавие от зулуса е било оправдано и подходящо (Христофоров, 2013, 432).

Освен всичко друго, тук ясно е заявено намерението повествованието да продължи и след „историческия акт от 9 септемврий 1944“. Самата теория първоначално е представена от лекомислена Сияна, която възкликва:

- Славянски обичай? Славянска душа! Та ние съвсем не сме славяни, а хуни [...] Собствено, в отделенията на основното училище ни казваха понякога, че сме славяни, но в по-горните класове на гимназията ни обясниха, че ние, българите, имаме много по-тесни родствени връзки с хуните, отколкото със славяните. Хуните, както знаете, са били могъщо и войнствено племе, което покорило голяма част от тогавашния свят. Вие, [...] лесно ще разберете, че е много по-приятно човек да се чувства пряк потомък на войнствените хуни, отколкото пра-пра-внук на някакви славянски овчари... (Христофоров, 2013, 443).

Десният Сандев също приема хунската теория, докато Агехев „примирително“ заключава, че „по този въпрос може да се спори“. Парадоксално наистина, но докато публикуваните текстове на Христофоров са критикувани по идеологически причини и съдържат твърде малко компромиси с режима, то при непубликуваните нещата са по-сложни. В Последните мацакуриии критиките към политическото статукво са наистина остри, но пък финалът като че ли носи някакво помирение с него - в края властта в селото все пак е завладяна от младите комунисти, които може би ще оправят нещата:

Израснало бе едно младо, съзнателно поколение, което не можеше вече да понася безобразията на своите бивши учители. И мацакурци избраха за председател на селсъвета младия Петре, който бе завършил само четвърто отделение, но в замяна бе минал през шестмесечна партийна школа; а за председател на кооперативното стопанство поставиха друг младеж, Иван Темерудката, изпитан комунист, завършил едва второ отделение.

На мацакурщината бе сложен край! [...] Шест месеца по-късно половината жители на Мацакурово се присъединиха към кооперативното стопанство и усърдно се заеха с построяването на социализма на село (Христофоров, 2012, 510).

Запазеният рькопис на Хунияда не достига до преврата от 1944 г. и поради това тук липсват подобни пасажи. Но тук, в края се открива един доста дълъг монолог на млад войник от село, който, нещо неприсъщо за 
Христофоров, проповядва някакъв селски утопизъм, противопоставен на корумпираната държава. Влюбеният в своята земя войник, разбира ce, е много далече от идеята за кооперирането на земята, което се задава на хоризонта, но той е много далече и от сметкаджийството на мацакурци, които също са привьрзани към своята земя, но по доста по-различен начин. Тук би могло да се открие известно противопоставяне между самоковските шопи и тракийците, или някаква форма на несьгласие с жестокото безсмислие на войната и какво ли още не. В Хунияда критиките към преддеветосептемврийския режим са открити и остри, но те са характерни за Христофоров още от времето на Скиции из Лондон. Хунияда несъмнено е и литературното произведение на Христофоров, в което той в най-голяма степен дава израз на икономическите си идеи за военновременната икономика и „военновременния капиталистически социализъм“, на които са посветени редица негови публикации, както преди, така и след преврата от 9 септември 1944 г. (Аретов, 2017).

В някои от публикуваните текстове на писателя могат да се открият и клишираните (което не значи непременно неискрени) фрази за партизаните. Тук на тях е посветена специална глава - На лов за хора, в която повествователят следва жандармерийската ловна дружина, но симпатиите му несъмнено са на страната на „шумарите“, представени като почти невинни жертви на жестоката власт. Не липсва дори описание на сражение, в което шумарите са героизирани. Зверствата на жандармеристите пък са сбито, но недвусмислено представени безсмислено убийство на дете, отрязани глави, набучени на колове и пр. Наистина текстът не е пълен, липсва една страница, но тя едва ли би променила общото впечатление.

Аналогичните епизоди в публикуваните Откровения (Христофоров, 2014, 489-517), които се разиграват на същото място и по същото време, са представени лаконично и без жестоките изстьпления на жандармеристите, което поражда възражения у някои критици.

$* * *$

Обяснението за непубликуването на разгледаните в началото текстове на Попович сякаш отвежда на първо място към авторовите скрупули, свързани с излагането на битови подробности от живота на своя 
опонент, а може би и с нежелание да демонстрира амбицията си да влезе в ролята на цивилизатор. Същевременно при Попович, както и при Иречек, скрупулите не препятстват записването на деликатните случки и заявяването на недвусмислено негативното отношение към опонента, останал неназован при Попович и поименно посочен в дневника на Иречек.

И за двете разглеждани тук творби на Христофоров може с увереност да се предположи, че издателските редактори (цензурата) биха изисквали ськращаване или сериозна преработка на значителна част от текста, ако въобще биха го приели. От друга страна, и в двата текста могат да се открият места, които, поне от днешна гледна точка приличат на тромаво и едва ли достатъчно убедително съобразяване с конюнктурата - митьт за добрите комунисти в Последните мащакурии, селската утопия в края на Хунияда. Може да се допусне, че Христофоров се е надявал някак да публикува тези творби. Хрисофоров съумява да придаде приемлив за цензурата вид на други свои текстове, които намекват за репресиите на комунистическата власт. Надежда, която ще да е била придружена с колебания, които остават Хунияда недовършена, въпреки че замисълът и планът са били готови.

В разгледаните тук текстове и на двамата автори се наблюдава някакво напрежение между желанието да се напише нещо и желанието и/или възможността то да достигне до читателите веднага. Предполагам, че някакво подобно напрежение (то може да бъде наречено и по друг начин) съществува и в непубликувани творби от други писатели. Струва ми се, че обяснението не би трябвало автоматично да се свежда до цензурата.

\section{Използвани архивни фондове}

НЛМ, № 88 (Асен Христофоров).

ЦДА ф. 988 (Васил Попович).

ЦДА, ф. 782 К, оп. 2, (Асен Христофоров).

[NLM, № 88 (Asen Hristoforov).

CDA f. 988 (Vasil Popovič).

CDA, f. 782 K, op. 2, (Asen Hristoforov)]. 


\section{Литература}

Андерсън, Б. (1998). Въобразените общности. Размишления върху произхода и разпространението на национализма. Прев. Я. Генова. София: Критика и хуманизъм.

Аретов, Н. (2000). Васил Попович. Живот и творчество. София: Кралица Маб. Аретов, Н. (2011a). Проблематичност и напрежение в славянската идентичност. Константин Иречек и българите. 3.03.2011. https://aretov.queenmab.eu/archives/balkans/75-problems-and-tensions-in-slav-identity.html. 21.11.2020.

Аретов, Н. (2011б). Непознатите мацакурии. 18.06.2011. https://aretov.queenmab. eu/archives/criticism/115-macakurci.html. 21.11.2020.

Аретов, Н. (2011в). Асен Христофоров: От Лондон до Мацакуричи през Белене. София: Кралица Маб.

Аретов, Н. (2017). Охрид в един непубликуван роман (,Хунияди“ на Асен Христофоров). 20.06.2017. https://aretov.queenmab.eu/archives/criticism/265-2017-0620-17-57-13.html. 21.11.2020.

Василев, Й. (1990). Интелектуалец от висок ранг. „Демокрация“ № 145, 10 август, с. 3.

Вълчев, Й. (2004). Дневниците на писателя дисидент. Предг., съст. и ред. Ив. Радев. В. Търново: Слово.

Делчев, Б. (1995). Дневник. Подб. М. Фъркова. София: Народна култура.

Динеков, П. (2016). Дневници. (1933-1992), т. 1. София: НБКМ.

Иречек. К. (1995). Български дневник, т. 2, София: София, Издателство Проф. Марин Дринов.

Константинов, К. (2011). Път през годините. Неиздадени спомени. София: НБКМ.

Мазганов, Д. (1988). Говедарици. София: Издателство на Отечествения фронт.

Миятев П. (подбрал и подготвил за печат) (1958). Из архива на Константин Иречек, т. 1. София: БАН.

Попович, В. (2000) Съчинения. Издирил и подготвил за печат Н. Аретов. София: Кралица Маб.

Саид. Е. (1999). Ориентализмът. Прев. Л. Дуков. София: Кралица Маб.

Христофоров, Ас. (2012). Избрани съчинения, т. 1. Съст. Н. Аретов. София: Кралица Маб.

Христофоров, Ас. (2013). Избрани съчинения, т. 2. Съст. Н. Аретов. София: Кралица Маб.

Христофоров, Ас. (2014). Избрани съчинения, т. 3. Съст. Н. Аретов. София: Кралица Маб.

Христофоров, Ас. (2018). Избрани съчинения, т. 4. Съст. Н. Аретов. София: Кралица Маб.

Христофоров, Ас. (1990а). Г-н Кандид от Говедаричи. „Литературен форум“ № 63, 6 септ.

Христофоров, Ас. (1990б). Пожелай ми безсъние. „Септември“ № 12. 
Христофоров, Ас. (2010). Избрани произведения и документи, т. 3. Обща редакция и встъпителна студия Р. Аврамов. София: БНБ.

Христофорова, Л. (1991). Епизоди от един живот. „Пламък“ № 2.

Чудомир (1994). Дневник (1947-1967). Казанлък: Фондация „Чудомир“-ИКК Славика-РМ.

[Anders"n, B. (1998). V"obrazenite obŝnosti. Razmišleniâ v"rhu proizhoda i razprostranenieto na nacionalizma. Prev. Â. Ženova. Sofiâ: Kritika i humaniz"m.

Aretov, N. (2000). Vasil Popovič. Život i tvorčestvo. Sofiâ: Kralica Mab.

Aretov, N. (2011a). Problematičnost i napreženie v slavânskata identičnost. Konstantin Ireček i b"lgarite. 3.03.2011. https://aretov.queenmab.eu/archives/balkans/75problems-and-tensions-in-slav-identity.html. 21.11.2020.

Aretov, N. (2011b). Nepoznatite macakurci. 18.06.2011. https://aretov.queenmab.eu/ archives/criticism/115-macakurci.html. 21.11.2020.

Aretov, N. (2011v). Asen Hristoforov: Ot London do Macakurci prez Belene. Sofiâ: Kralica Mab.

Aretov, N. (2017). Ohrid v edin nepublikuvan roman (,Huniâdi“ na Asen Hristoforov).20.06.2017.https://aretov.queenmab.eu/archives/criticism/265-2017-06-2017-57-13.html. 21.11.2020.

Vasilev, J. (1990). Intelektualec ot visok rang. „Demokraciâ““ № 145, 10 avgust, s. 3.

V"lčev, J. (2004). Dnevnicite na pisatela disident. Predg., s"st. i red. Iv. Radev. V. T"rnovo: Slovo.

Delčev, B. (1995). Dnevnik. Podb. M. F"rkova. Sofiâ: Narodna kultura.

Dinekov, P. (2016). Dnevnici. (1933-1992), t. 1. Sofiâ: NBKM.

Ireček. K. (1995). B"lgarski dnevnik, t. 1-2, Sofiâ: Izdatelstvo Prof. Marin Drinov.

Konstantinov, K. (2011). P"t prez godinite. Neizdadeni spomeni. Sofiâ: NBKM.

Mazganov, D. (1988). Govedarci. Sofiâ: Izdatelstvo na Otečestveniâ front.

Miâtev, P. (podbral i podgotvil za pečat) (1956). Iz arhiva na Konstantin Ireček, t. 1. Sofiâ: BAN.

Popovič, V. (2000) S"čineniâ. Izdiril i podgotvil za pečat N. Aretov. Sofiâ: Kralica Mab. Said, E. (1999). Orientalizm"t. Prev. L. Dukov. Sofiâ: Kralica Mab.

Hristoforov, As. (2012-2018). Izbrani s"čineniâ, t. 1-4. S"st. N. Aretov. Sofiâ: Kralica Mab.

Hristoforov, As. (1990a). G-n Kandid ot Govedarci. „Literaturen forum“ № 63, 6 sept. Hristoforov, As. (1990b). Poželaj mi bezs"nie. „Septemvri“ № 12.

Hristoforov, As. (2010). Izbrani proizvedeniâ i dokumenti, t. 1-3. Obŝa redakciâ i vst"pitelna studiâ R. Avramov. Sofiâ: BNB.

Hristoforova, L. (1991). Epizodi ot edin život. „Plam”k“” № 2.

Čudomir (1994). Dnevnik (1947-1967). Kazanl”k: Fondaciâ „Čudomir“-IKK Slavika-RM].

Todorova, M. (1997). Imagining the Balkans. New York-Oxford: Oxford University Press. 